\title{
Number of Dental Stem Cells on Root Canal Dentin after Application of Triple Antibiotic Paste or Calcium Hydroxide: An In Vitro Study
}

\author{
Konstantinos Gougousis ${ }^{1} \quad$ Dimitrios G. Giannakoulas ${ }^{1} \quad$ Vasiliki Taraslia ${ }^{2} \quad$ Anastasia Agrafioti $^{1}$ \\ Ema Anastasiadou ${ }^{2}$ Evangelos G. Kontakiotis ${ }^{1}$
}

${ }^{1}$ Department of Endodontics, School of Dentistry, National and
Kapodistrian University of Athens, Athens, Greece
${ }^{2}$ Department of Genetics and Gene Therapy, Biomedical Research
Foundation of the Academy of Athens, Athens, Greece

\begin{abstract}
Address for correspondence Evangelos G. Kontakiotis, DDS, PhD Department of Endodontics, School of Dentistry, National and Kapodistrian University of Athens, Athens, Greece (e-mail: ekontak@dent.uoa.gr).
\end{abstract}

Eur J Dent 2019;13:161-165

\begin{abstract}
Keywords

- calcium hydroxide

- regenerative endodontics

- stem cells

- triple antibiotic paste
\end{abstract}

Objective The aim of this study was to evaluate the viability of stem cells from exfoliated and deciduous teeth (SHED) on dentin surface treated with triple antibiotic paste or calcium hydroxide.

Materials and Methods Nine single-rooted extracted premolars were prepared appropriately and divided into three groups. In group A, the root canals were left empty, a triple antibiotic paste was placed in the root canals of group $B$, and calcium hydroxide was placed in the root canals of group C. After 1 week, the intracanal medicaments were removed, and stem cells were seeded on the treated surface of the specimens for 1 more week. The cells were stained and then observed under confocal microscope over the entire surface of each test material. Counting of the cells was made by Image J (3D) software, as well as manually.

Statistical Analysis To investigate any statistically significant differences between the experimental groups, statistical tests including Kruskal-Wallis and Mann-Whitney $\mathrm{U}$-test were performed. Significance level was set to $P<0.05$, and all analyses were performed with SPSS IBM program, v. 21.

Results Groups $B$ and $C$ showed statistically significantly higher number of cells compared to Group A, whereas cells developed in a substrate of calcium hydroxide residues appeared in majority with distinct cores and widened unlike other groups.

Conclusions The effect of calcium hydroxide manifested better results regarding the number of stems cells on root canal surfaces.

\section{Introduction}

The term "regenerative endodontics" includes the total amount of therapeutic procedures based on biological properties and processes designed to restore damaged structures of the tooth. ${ }^{1}$ Today, the principles of regenerative endodontics find clinical application in teeth with pulp necrosis and open apex, where the purpose of treatment is to promote continued root development and recover pulp function. ${ }^{1,2}$ Many clinical studies have been published concerning these procedures. However, the different methodology followed in each case, as well as the lack of randomized clinical studies, does not allow the definition of a predictable clinical protocol. ${ }^{3}$

A necessary procedure for the success of regenerative endodontic procedures (REPs) is the disinfection of the root canal system, as it enables pulpal and apical healing. ${ }^{4}$ REPs are mostly based on chemical disinfection of the root canals. Hoshino et al developed the triple antibiotic paste (TAP) consisting of metronidazole, ciprofloxacin, and minocycline, which has been widely used in cases of revascularization because of its effectiveness in disinfection of the infected necrotic tooth. ${ }^{3,5}$ Double antibiotic paste (DAP) 
which consists of metronidazole and ciprofloxacin, as well as calcium hydroxide $\left[\mathrm{Ca}(\mathrm{OH})_{2}\right]$, has also been proposed as intracanal medicaments during REPs. ${ }^{6,7}$

Clinically used concentrations of TAP and DAP were found to have toxic effects on stem cells from apical papilla $(\mathrm{SCAP})^{8-11}$ and dental pulp stem cells (DPSCs). ${ }^{12}$ On the other hand, low concentrations of TAP, DAP, as well as the clinically used concentration of $\mathrm{Ca}(\mathrm{OH})_{2}$ were found to be nontoxic to SCAP and DPSCs. ${ }^{10-12}$

As complete removal of intracanal medicaments from the root canal system has been found to be impossible, ${ }^{13}$ the effect of the residues on stems cells seems to be crucial. The effects of the application of antibiotics or $\mathrm{Ca}(\mathrm{OH})_{2}$, as well as their residual quantities on root canal dentin on cells' viability and attachment, have barely been investigated..$^{14}$ The aim of this study was to evaluate the number and morphological characteristics of stem cells from exfoliated and deciduous teeth (SHED) on dentin surfaces after the application TAP or $\mathrm{Ca}(\mathrm{OH})_{2}$.

\section{Materials and Methods}

\section{Specimen Preparation}

Nine intact, single-rooted human mandibular premolars extracted for orthodontic reasons were recruited in this study. After cutting off the crowns, all teeth were prepared to a uniform length of $10 \mathrm{~mm}$, using a circular saw blade. Specimens were measured to the nearest $0.5 \mathrm{~mm}$. A channel was created with a cutting diamond disc along the longitudinal axis of the tooth, without entering the root canal, to facilitate subsequent separation of the root. For cleaning and shaping, a step-back technique was used up to a K-file \#60 (Dentsply Maillefer, Ballaigues, Switzerland) as a master apical file, and coronal flaring was performed with Gates-Glidden No. 2, 3, and 4 (Gates-Glidden drills, Mani Co, Japan). During the instrumentation, the root canals were rinsed with $20 \mathrm{ml} \mathrm{NaO}-$ Cl 2.5\% (Farmaka Marinopoulos, Athens, Greece). Afterward, they were dried with paper points (DiaDent, Almere, Netherlands). Specimens were divided into three groups (A, B, and $C)$ according to the intracanal medicament that was used as follows: group A (control group)-the root canals were left empty; group B-a triple antibiotic paste of metronidazole (Sanofi-Aventis, Athens, Greece), minocycline (Teofarma S. r. 1, Pavia, Italy), and ciprofloxacin (Bayer Hellas, Athens, Greece), according to Hoshino et al's protocol, ${ }^{5}$ was placed in the root canals with a Lentulo spiral; group $\mathrm{C}-$ pure $\mathrm{Ca}(\mathrm{OH})_{2}$ powder mixed with sterile saline (Baxter Hellas, Athens, Greece) (6:4) was placed in the root canals with a Lentulo spiral (VDW, Munich, Germany). All samples were wrapped in sterile gauze soaked in saline and were stored in a sealed container, in an incubator at $37^{\circ} \mathrm{C}$ for 7 days. In order to remove the medicament, samples were irrigated with $30 \mathrm{~mL}$ of $\mathrm{NaOCl} 2.5 \%$, and a final irrigation with $10 \mathrm{ml}$ sterile saline was performed.

After the removal of the medicaments, the root canals were dried with paper points, and the roots were dissected along the longitudinal axis using a chisel which was placed in the channel that was originally created. From each root emerged two samples that would play the role of a "tank" in which the stem cells were placed ( $n=6 /$ group).

\section{Cell Culture}

SHEDs were provided by ProCell, Biotechnological Applications, SA (Athens, Greece). Once thawing, they were immediately transferred and cultured in Dulbecco's Modified Eagle's Medium (Gibco, Glasgow, UK), at $37^{\circ} \mathrm{C}$, in an incubator of constant temperature and $\mathrm{CO}_{2}$ concentration. The culture medium was supplemented with sodium pyruvate, streptomycin, penicillin, and L-glutamine and completed with $10 \%$ fetal calf serum heat-inactivated (Biochrom, Cambridge, UK). Cells used for this experiment were between the third and sixth passages. For routine cell counts, the cells were resuspended in Trypan Blue solution (Gibco, Glasgow, $\mathrm{UK}$ ), and classical hemacytometer was applied (Neubauer) to determine the population of cells and their viability. On each treated surface of the root canals, 100,000 cells were plated and were cultured in a complete medium for 7 days.

\section{Immunofluorescent Staining and Confocal Microscopy}

After 7 days in culture, cells on dentine parts were fixed in $4 \%$ paraformaldehyde solution for $20 \mathrm{~min}$ at room temperature. Then, the cells were rinsed with phosphate-buffered saline (PBS) to remove excess paraformaldehyde. After that, cytoplasmic membrane of the cells was processed with buffer $B(0.1 \%$ Triton X-100 in PBS buffer) for $10 \mathrm{~min}$ and then with buffer $A$ ( $0.5 \%$ Triton X-100 in PBS) for another $10 \mathrm{~min}$. This step was performed three times, followed by incubation in a blocking solution of nonspecific antibody-binding sites (BSA-bovine serum albumin-0.5\% w/v, in $1 \mathrm{x}$ PBS solution) for $90 \mathrm{~min}$ at room temperature. Thereafter, a solution of rhodamine phalloidin (Molecular Probes, ThermoFisher Scientific, Grand Island, New York) was added to stain actin for $30 \mathrm{~min}$. For the observation of intact nuclei stain, 4', 6-diamidino-2-phenylindole was used.

The sample cells were observed under a confocal microscope in order to measure the number of adherent cells and to evaluate their morphological characteristics. Fluorescence images were acquired with a confocal microscope and then they were analyzed by Zeiss software (ZEISS, Germany). The examination of each sample was made with the confocal microscope over the entire surface of each test material. Cells were counted using the cell counter plug-in of Image J (3D) software (Open source software project), as well as manually, and the average number of cells was calculated.

\section{Statistical Analysis}

To investigate any statistically significant differences in the mean values of cell number fraction per unit area $\left(\mathrm{mm}^{2}\right)$ (nonnormal distribution) between the experimental groups and by method, statistical tests such as Kruskal-Wallis and Mann-Whitney U-tests were performed. Significance level was set to $p<0.05$, and all analyses were performed using SPSS IBM program, v. 21 (IBM Corporation, New York).

\section{Results}

The number of cells in groups B and C, with both cell-counting methods, was statistically significantly higher in comparison to the control group (group A) (-Tables 1 and $\mathbf{2}$ ). 
Table 1 Mean values \pm standard deviations of cell number per surface area $\left(\mathrm{mm}^{2}\right)$ by method and by experimental group

\begin{tabular}{|l|l|l|l|}
\hline Method & Group A (control) & Group B (TAP) & Group C (Ca[OH $\left.]_{2}\right)$ \\
\hline Manual count & $9.1 \pm 1.71$ & $14.65 \pm 1.6$ & $16.65 \pm 2.33$ \\
\hline Kruskal-Wallis $(P)$ & $<0.002$ & $15.2 \pm 1.81$ & $18.28 \pm 5.37$ \\
\hline 3D count & $9.3 \pm 1.7$ & \multicolumn{3}{|l|}{} \\
\hline Kruskal-Wallis $(P)$ & $<0.003$ &
\end{tabular}

Abbreviations: $\mathrm{Ca}(\mathrm{OH})_{2}$, calcium hydroxide; TAP, triple antibiotic paste.

Table 2 Comparison of all possible cell number differences between the experimental groups (post hoc analysis) per method

\begin{tabular}{|c|l|}
\hline & $p$-Value \\
\hline Manual count & \\
\hline Control versus antibiotic & 0.004 \\
\hline Control versus $\mathrm{Ca}(\mathrm{OH})_{2}$ & 0.004 \\
\hline Antibiotic versus $\mathrm{Ca}(\mathrm{OH})_{2}$ & Statistically non significant \\
\hline $3 \mathrm{D}$ count & \\
\hline Control versus antibiotic & 0.004 \\
\hline Control versus $\mathrm{Ca}(\mathrm{OH})_{2}$ & 0.004 \\
\hline $\begin{array}{l}\text { Antibiotic versus } \\
\mathrm{Ca}(\mathrm{OH})_{2}\end{array}$ & Nonstatistically significant \\
\hline
\end{tabular}

Abbreviation: $\mathrm{Ca}(\mathrm{OH})_{2}$, calcium hydroxide.

Regarding cell morphology, representative images of cells cultured on root dentine are shown in $\mathbf{- F i g}$. 1. Cells cultured on dentin with calcium hydroxide residues appeared with distinct cores and widened, demonstrating a polarized morphology with elongated cytoskeleton with multiple thin processes ( - Fig. 1E and F). On the contrary, cells in both other groups (A and B) appeared to abolish their typical spindle-shaped appearance, becoming more circular ( - Fig. 1A-D).

\section{Discussion}

The intracanal medicaments used in REPs must be selected not only based on their antimicrobial properties, but also on their ability to enable or even to promote survival, proliferation, and differentiation of the patient's stem cells. The most popular intracanal medicaments currently being used in REPs are antibiotic combination paste (TAP) and calcium hydroxide. ${ }^{15}$ The current in vitro study tries to enhance the data concerning the aforementioned considerations, by comparing the survival, proliferation, and differentiation of stem cells on dentine surface covered with residues of those two most commonly used intracanal medicaments. Recent in vitro studies detected detrimental effects of antibiotic pastes at high concentrations on SCAP survival, whereas $\mathrm{Ca}(\mathrm{OH})_{2}$ promoted the proliferation of SCAPs. ${ }^{9,10}$ TAP has been associated as well, with tooth discoloration, because of minocycline that exists in the mixture ${ }^{16}$; hence, alternatives, such as DAP, have been used instead. ${ }^{17}$ On the other hand, it has been reported that TAP $(10 \mathrm{mg} / \mathrm{mL})$ was more effective than both DAP and Ultracal $\mathrm{Ca}(\mathrm{OH})_{2}$ as disinfectant of the root canal system while allowing the survival of a small percentage of SCAPs. ${ }^{18}$
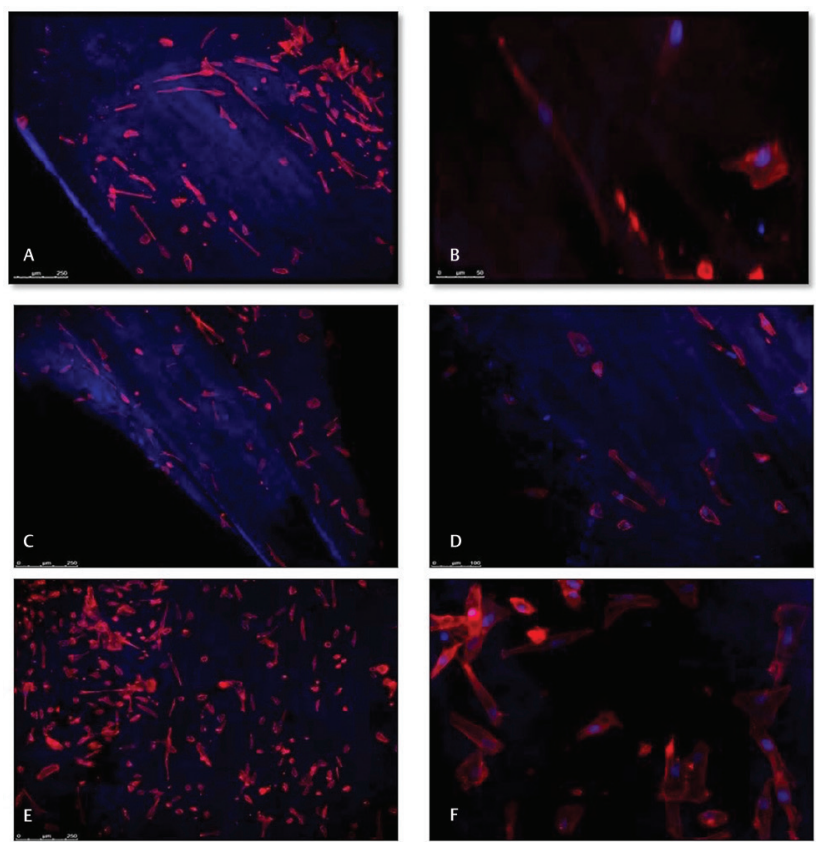

Fig. 1 The appearance of stem cells that developed on the surface by confocal microscopy, magnification $\times 10($ A), $\times 20(B)$, in a substrate of TAP residues, magnification $\times 10$ (C), $\times 20$ (D), and in a substrate of calcium hydroxide residues, magnification $\times 10(\mathbf{E}), \times 20(\mathbf{F})$.

It is known that the complete removal of $\mathrm{Ca}(\mathrm{OH})_{2}$, as well as antibiotics from the root canal, even after extensive irrigation, is not feasible. ${ }^{13}$ At the same time, it is unknown whether the residual quantities of antibiotics are in concentrations that make the medicament toxic for stem cells. ${ }^{19-21}$ Since complete intracanal medicament removal is not possible, this study evaluated the survival ability and characteristics of viable cells on dentine surfaces treated with TAP and $\mathrm{Ca}(\mathrm{OH})_{2}$ by using immunofluorescent staining and confocal microscopy.

Single-rooted teeth were selected to ensure sufficient pulp cavity. The processing was performed by the same technique and the same volume of irrigating for each group. No ethylenediaminetetraacetic acid or citric acid was used, as it has been found that they modulate a positive scaffold for cell growth. ${ }^{22}$ Multiple studies recommend the use of EDTA as final irrigation during REPs, to promote stem cell attachment, proliferation, and differentiation, to release growth factors from dentine surface, ${ }^{22,23}$ as well as to neutralize the cytotoxic effects of $\mathrm{NaOCl}^{8}$ and intracanal medicaments. ${ }^{12} \mathrm{~A}$ recent in vitro study found that, although EDTA treatment improved stem cell adhesion, it did not 
improve their proliferation on dentine. ${ }^{24}$ The difference between the aforementioned studies ${ }^{22-24}$ regarding stem cells' proliferation might be due to a different methodology that was carried out in each study. Due to modifications of EDTA on dentine surface and as this study focuses on the effect of intracanal medicaments on stem cells' viability, EDTA irrigation was excluded from the protocol used in the current in vitro study.

The use of SHED does not completely simulate the clinical conditions; however, the choice of these cells was relied on their high proliferative potency and their capacity to create a dental pulp-like tissue. ${ }^{25-27}$ Furthermore, another reason for that choice was that SHEDs were recently used during the application of an injectable technique using scaffolds and SHED toward the formation of pulp-like tissue..$^{28}$

Calcium hydroxide and TAP seemed to promote SHED development in a statistically significant way compared to control group, both by manual and software counting ( - Table 1). This could indicate that residues of the intracanal medicaments might assist in the success of REPs. Although TAP favored cell development, it appeared that the qualitative characteristics of the cells were inferior to those grown in the presence of $\mathrm{Ca}(\mathrm{OH})_{2}(-$ Fig. 1). Cells that were grown in a substrate of calcium hydroxide residues appeared widened and with more distinct cores (-Fig. 1E, F), characteristics that make them more able to survive, further proliferate, and potentially differentiate. This contrasts with the existing view in clinical practice that the calcium hydroxide should be avoided in regenerative endodontics for potential toxicity to stem cells. ${ }^{29}$ In an in vitro study, Ruparel et al reported that $\mathrm{Ca}(\mathrm{OH})_{2}$ was nontoxic at all concentrations tested, and appeared to promote proliferation of SCAP at certain concentrations. ${ }^{9}$ One possible mechanism that helps the growth of cells could be the release of growth factors contained in dentin by alkaline hydrolysis that takes place. ${ }^{30}$ Also, in vitro studies have shown that $\mathrm{Ca}(\mathrm{OH})_{2}$ improved cellular attachment to dentine ${ }^{14}$ and release of TGF- $\beta 1,{ }^{31-33}$ which suggests positive influences of $\mathrm{Ca}(\mathrm{OH})_{2}$ on dentine regeneration.

\section{Conclusions}

Two conclusions can be drawn from this study:

1. Number of stem cells on root canal surfaces having undergone the action of calcium hydroxide or TAP manifested more satisfactory results compared to that of the control group

2. The development of stem cells on root canal surfaces having undergone the action of calcium hydroxide is qualitatively better than the quality of stem cells grown on surfaces that have been subjected to the action of the triple antibiotic.

\section{Funding}

None.

\section{Conflict of Interest}

None declared.

\section{References}

1 Murray PE, Garcia-Godoy F, Hargreaves KM. Regenerative endodontics: a review of current status and a call for action. J Endod 2007;33(4):377-390

2 Banchs F, Trope M. Revascularization of immature permanent teeth with apical periodontitis: new treatment protocol? J Endod 2004;30(4):196-200

3 Kontakiotis EG, Filippatos CG, Tzanetakis GN, Agrafioti A. Regenerative endodontic therapy: a data analysis of clinical protocols. J Endod 2015;41(2):146-154

4 Yanpiset K, Trope M. Pulp revascularization of replanted immature dog teeth after different treatment methods. Endod Dent Traumatol 2000;16(5):211-217

5 Hoshino E, Kurihara-Ando N, Sato I, et al. In-vitro antibacterial susceptibility of bacteria taken from infected root dentine to a mixture of ciprofloxacin, metronidazole and minocycline. Int Endod J 1996;29(2):125-130

6 Iwaya SI, Ikawa M, Kubota M. Revascularization of an immature permanent tooth with apical periodontitis and sinus tract. Dent Traumatol 2001;17(4):185-187

7 Cehreli ZC, Isbitiren B, Sara S, Erbas G. Regenerative endodontic treatment (revascularization) of immature necrotic molars medicated with calcium hydroxide: a case series. J Endod 2011;37(9):1327-1330

8 Trevino EG, Patwardhan AN, Henry MA, et al. Effect of irrigants on the survival of human stem cells of the apical papilla in a platelet-rich plasma scaffold in human root tips. J Endod 2011;37(8):1109-1115

9 Ruparel NB, Teixeira FB, Ferraz CC, Diogenes A. Direct effect of intracanal medicaments on survival of stem cells of the apical papilla. J Endod 2012;38(10):1372-1375

10 Althumairy RI, Teixeira FB, Diogenes A. Effect of dentin conditioning with intracanal medicaments on survival of stem cells of apical papilla. J Endod 2014;40(4):521-525

11 Martin DE, De Almeida JF, Henry MA, et al. Concentrationdependent effect of sodium hypochlorite on stem cells of apical papilla survival and differentiation. J Endod 2014;40(1):51-55

12 Kim KW, Yassen GH, Ehrlich Y, Spolnik K, Platt JA, Windsor LJ. The effects of radicular dentine treated with double antibiotic paste and ethylenediaminetetraacetic acid on the attachment and proliferation of dental pulp stem cells. Dent Traumatol 2015;31(5):374-379

13 Lambrianidis T, Kosti E, Boutsioukis C, Mazinis M. Removal efficacy of various calcium hydroxide/chlorhexidine medicaments from the root canal. Int Endod J2006;39(1):55-61

14 Kitikuson P, Srisuwan T. Attachment ability of human apical papilla cells to root dentin surfaces treated with either 3Mix or calcium hydroxide. J Endod 2016;42(1):89-94

15 Diogenes A, Henry MA, Teixeira FB, Hargreaves KM. An update on clinical regenerative endodontics. Endod Topics 2013;28(1):2-23

16 Kim JH, Kim Y, Shin SJ, Park JW, Jung IY. Tooth discoloration of immature permanent incisor associated with triple antibiotic therapy: a case report. J Endod 2010;36(6):1086-1091

17 Hargreaves KM, Diogenes A, Teixeira FB. Treatment options: biological basis of regenerative endodontic procedures. J Endod 2013;39(3, Suppl):S30-S43

18 Latham J, Fong H, Jewett A, Johnson JD, Paranjpe A. Disinfection efficacy of current regenerative endodontic protocols in simulated necrotic immature permanent teeth. J Endod 2016;42(8):1218-1225

19 Rödig T, Vogel S, Zapf A, Hülsmann M. Efficacy of different irrigants in the removal of calcium hydroxide from root canals. Int Endod J 2010;43(6):519-527

20 Taşdemir T, Celik D, Er K, Yildirim T, Ceyhanli KT, Yeşilyurt C. Efficacy of several techniques for the removal of calcium hydroxide medicament from root canals. Int Endod J 2011;44(6):505-509 
21 Berkhoff JA, Chen PB, Teixeira FB, Diogenes A. Evaluation of triple antibiotic paste removal by different irrigation procedures. J Endod 2014;40(8):1172-1177

22 Pang NS, Lee SJ, Kim E, et al. Effect of EDTA on attachment and differentiation of dental pulp stem cells. J Endod 2014;40(6):811-817

23 Galler KM, Widbiller M, Buchalla W, et al. EDTA conditioning of dentine promotes adhesion, migration and differentiation of dental pulp stem cells. Int Endod J 2016;49(6):581-590

24 Alghilan MA, Windsor LJ, Palasuk J, Yassen GH. Attachment and proliferation of dental pulp stem cells on dentine treated with different regenerative endodontic protocols. Int Endod J 2017;50(7):667-675

25 Miura M, Gronthos S, Zhao M, et al. SHED: stem cells from human exfoliated deciduous teeth. Proc Natl Acad Sci U S A 2003;100(10):5807-5812

26 Cordeiro MM, Dong Z, Kaneko T, et al. Dental pulp tissue engineering with stem cells from exfoliated deciduous teeth. J Endod 2008;34(8):962-969

27 Sakai VT, Zhang Z, Dong Z, et al. SHED differentiate into functional odontoblasts and endothelium. J Dent Res 2010;89(8):791-796
28 Rosa V, Zhang Z, Grande RH, Nör JE. Dental pulp tissue engineering in full-length human root canals. J Dent Res 2013;92(11):970-975

29 Wigler R, Kaufman AY, Lin S, Steinbock N, Hazan-Molina H, Torneck CD. Revascularization: a treatment for permanent teeth with necrotic pulp and incomplete root development. J Endod 2013;39(3):319-326

30 Ballal NV, Shavi GV, Kumar R, Kundabala M, Bhat KS. In vitro sustained release of calcium ions and $\mathrm{pH}$ maintenance from different vehicles containing calcium hydroxide. J Endod 2010;36(5):862-866

31 Graham L, Cooper PR, Cassidy N, Nor JE, Sloan AJ, Smith AJ. The effect of calcium hydroxide on solubilisation of bio-active dentine matrix components. Biomaterials 2006;27(14):2865-2873

32 Tomson PL, Grover LM, Lumley PJ, Sloan AJ, Smith AJ, Cooper PR. Dissolution of bio-active dentine matrix components by mineral trioxide aggregate. J Dent 2007;35 (8):636-642

33 Galler KM, Buchalla W, Hiller KA, et al. Influence of root canal disinfectants on growth factor release from dentin. J Endod 2015;41(3):363-368 